\title{
Titania and Titania-Silica Coatings for Titanium: Comparison of Ectopic Bone Formation within Cell-Seeded Scaffolds*
}

\author{
VILLE V. MERETOJA, M.Sc., ${ }^{1}$ TEEMU TIRRI, D.D.S., ${ }^{1}$ VIRPI ÄÄRITALO, M.Sc., \\ X. FRANK WALBOOMERS, Ph.D., ${ }^{3}$ JOHN A. JANSEN, D.D.S., Ph.D., ${ }^{3}$ and TIMO O. NÄRHI, D.D.S., Ph.D. ${ }^{1}$
}

\begin{abstract}
The aim of this study was to compare titania $\left(\mathrm{TiO}_{2}\right)$-coated, titania-silica ( $\left.\mathrm{TiSi}\right)$-coated, and uncoated (cpTi) titanium fiber meshes as scaffolds for bone engineering. The scaffolds were loaded with bone marrow stromal cells and implanted subcutaneously in rats. Ectopic bone formation after 1, 4, and 12 weeks of implantation was evaluated using histology and histomorphometry. After 1 week of implantation, multiple patches of unorganized mineralizing tissue were seen in all implants. The amount of this bone-like tissue clearly increased from 1 to 4 weeks. Bone apposition occurred in direct contact with coated meshes, while a thin layer of unmineralized fibrous tissue was often observed surrounding cpTi mesh fibers. After 12 weeks, the structure of bone, with bone marrow-like tissue, was further matured and mesh fibers were embedded in lamellar bone. No statistical differences in the amount of mineralized bone were observed between scaffold types at any point of time. Only TiSi scaffolds showed further increase in bone area from 4 to 12 weeks $(p<0.01)$. A notable difference was that the sol-gel coatings resulted in enhanced initial bone contact and distribution of bone tissue, whereas uncoated implants showed bone formation mainly in the center of the scaffolds. In conclusion, $\mathrm{TiO}_{2}$-based sol-gel coatings may be used in tissue engineering to gain more uniform distribution of bone throughout titanium fiber mesh scaffolds.
\end{abstract}

\section{INTRODUCTION}

B ONE GRAFTS ARE OFTEN USED to reconstruct bone defects, and autogenous grafts are considered a golden standard in the procedure. However, the use of autogenous bone grafts is restricted by donor-site morbidity and the additional surgical procedure under general anesthesia needed for harvesting the graft. This is an important aspect as most of the patients are at an advanced age and the use of autogenous bone grafts is impossible in many of them. Hence new strategies to reconstruct bone defects are urgently needed. Tissue engineering strategies can be utilized in many cases of bone reconstruction provided that proper scaffold materials are available. ${ }^{1-3}$
In cell-based bone engineering strategies, osteogenic cells are incorporated into implanted scaffolds to supply adequate cells for tissue regeneration. These may be stem cells or progenitor cells capable of producing bone tissue and boneinducing growth factors. The most common source of cells are mesenchymal stem cells derived from bone marrow. These cells can be expanded and induced to osteogenic lineage in vitro to obtain a suitable cell population for further in vivo applications. ${ }^{4,5}$

Ectopic implantation is a widely used method to assess biological response to bone engineering constructs. The effects of scaffold properties on bone formation can be systematically evaluated in comparative studies using multiple scaffold types. Such experiments have been conducted to

\footnotetext{
${ }^{1}$ Department of Prosthetic Dentistry and Biomaterials Science, Institute of Dentistry, University of Turku, Turku, Finland.

${ }^{2}$ Turku Biomaterials Centre, Institute of Dentistry, University of Turku, Turku, Finland.

${ }^{3}$ Department of Periodontology and Biomaterials, University Medical Center Nijmegen, Nijmegen, The Netherlands.

*Part of these data have been previously presented as an abstract in J Dent Res 84 (Special Issue A), $2107,2005$.
} 
analyze the importance of, for example, porous design ${ }^{6-8}$ and bulk ${ }^{9-12}$ or surface ${ }^{13,14}$ chemistry of the scaffolds.

Sintered titanium fiber mesh loaded with bone marrow stromal cells has previously been used as a mechanically strong bone graft substitute. ${ }^{15}$ However, meshes that are not loaded with cells show only minor osteoconductive properties. Proposed methods to increase the osteoconductivity of titanium metal include alkali-heat treatment, ${ }^{16}$ anodic oxidation, ${ }^{17-19}$ and use of sol-gel-derived titania $\left(\mathrm{TiO}_{2}\right)$ coatings. ${ }^{20}$ Sol-gel dip-coating method can be used to produce nanoporous $\mathrm{TiO}_{2}$ surface on commercially pure titanium, and such thin films have been found to induce calcium phosphate precipitation on their surface. ${ }^{21}$ Further, the bioactivity of silica-containing bioceramics ${ }^{22}$ has led to the development of mixed titania-silica (TiSi) coatings. ${ }^{23}$ Indeed, the osteoblast response on planar surfaces, ${ }^{24}$ but not in porous scaffolds, ${ }^{25}$ was found to be enhanced by incorporation of a reactive silica phase in the $\mathrm{TiO}_{2}$ coating. We therefore hypothesize that nonresorbable bioactive coatings based on $\mathrm{TiO}_{2}$, with or without a silica phase, can enhance bone formation in vivo.

The aim of the current study was to compare ectopic bone formation in rats with $\mathrm{TiO}_{2}$-coated, TiSi-coated, and uncoated implants loaded with bone marrow stromal cells. This is the first time that such coated tissue engineering scaffolds are tested in vivo. Bone formation after 1, 4, and 12 weeks of implantation was evaluated using histology and histomorphometry.

\section{MATERIALS AND METHODS}

\section{Scaffold preparation}

A sintered titanium fiber mesh (Bekaert N.V., Zwevegem, Belgium) with a volumetric porosity of $86 \%$, a density of $600 \mathrm{~g} / \mathrm{m}^{2}$, a fiber diameter of $40 \mu \mathrm{m}$, and an average distance between fibers of $250 \mu \mathrm{m}$ was used. Of this mesh, discshaped specimens $6 \mathrm{~mm}$ in diameter and $0.8 \mathrm{~mm}$ thick were cut, and used as such (cpTi), or coated with $\mathrm{TiO}_{2}$ or a 30:70 mol\% mixture of titania and silica (TiSi) using a previously described sol-gel technique. ${ }^{25}$

Briefly stated, the titanium fiber mesh substrates were cleaned ultrasonically in acetone and ethanol $(5+5$ minutes $)$, and dried in air before each dipping and heating cycle. The two different coatings were achieved by dipping the substrates into respective sols and then withdrawing them at a speed of $0.3 \mathrm{~mm} / \mathrm{second}$. The substrates were then heated at $500^{\circ} \mathrm{C}$ for 10 minutes. The dipping and heating cycle was repeated five times. Uncoated and coated scaffolds were finally cleaned ultrasonically and sterilized using gamma radiation (25 kGy minimum).

\section{Cell culture and implant preparation}

Rat bone marrow was harvested and cultured according to the procedure given by Maniatopoulos et al. ${ }^{26}$ Briefly said, the femurs of four 6-week-old male adult (100-110 g) syngeneic Fisher 344 rats (F344/NHsd, Harlan, the Netherlands) were retrieved directly after the animals were sacrificed. The bones were wiped with $70 \%$ alcohol and immersed twice in alpha-minimum essential medium (alpha-MEM) (Sigma Chemical, St. Louis, MO) culture medium containing 100 units/mL of penicillin/streptomycin (Gibco BRL, Life Technologies BV, Breda, the Netherlands). The condyles were cut off and bone marrow was flushed out using complete cell culture medium (alpha-MEM, antibiotics supplemented with $15 \%$ fetal bovine serum (Gibco), $50 \mu \mathrm{g} / \mathrm{mL}$ ascorbic acid (Sigma), $8.5 \mathrm{mM}$ Na- $\beta$-glycerophosphate (Merck, Darmstadt, Germany), and $10 \mathrm{nM}$ dexamethasone (Sigma)). The resulting suspension was passed through a $22 \mathrm{G}$ needle, and plated cells were cultured in a humidified $5 \%$ carbon dioxide $\left(\mathrm{CO}_{2}\right)$ atmosphere at $37^{\circ} \mathrm{C}$.

After 7 days of primary culture, the adherent osteoblastlike cell population was enzymatically detached $(0.25 \%$ trypsin/0.02\% EDTA (Sigma)), and a stock of $1.5 \times 10^{6}$ cells/ $\mathrm{mL}$ was prepared in complete culture medium. Titanium fiber meshes were incubated in complete medium for 3 hours before cell suspension $(\sim 0.15 \mathrm{~mL}$ per mesh) was added to each type of substrate in polypropylene tubes. Cells were allowed to adhere at $37^{\circ} \mathrm{C}$ for 2.5 hours under continuous rotation $(6 \mathrm{rpm})$. Substrates were subsequently transferred to 24-well plates and cultured overnight. The next day, substrates were placed into serum-free medium and translocated to the animal facility. Substrates were kept at $37^{\circ} \mathrm{C}$ during surgery, and washed with phosphate buffered saline before implantation.

\section{Implantation procedure}

For implantation, eighteen 3-week-old male ( 25 to $40 \mathrm{~g}$ ) syngeneic Fisher 344 rats were used. The experiment was approved by the Lab-Animal Care \& Use Committee at the University of Turku, Finland (licence \#953/99). Experiment was conducted in good laboratory practice (GLP) compliant laboratory animal facilities, and national and European regulations for animal experimentation were followed. Operations were performed under general anesthesia induced by subcutaneous injection of fentanyl citrate/fluanisone (Hypnorm ${ }^{\circledR}$, Janssen Pharmaceutica, Beerse, Belgium) and midatzolam (Dormicum ${ }^{\circledR}$, Roche, Basel, Switzerland). The operation area was shaved and disinfected with chlorhexidine gluconate solution (Klorhexol®, Leiras, Turku, Finland).

Subcutaneous implantation was performed through two longitudinal incisions in the midline of the dorsal skin. Individual implant beds were prepared by blunt dissection. Each animal received one of each implant type (total three). One implant was placed on the left and two on the right flank of the animals using Latin Square randomization scheme. Skin wounds were closed in two layers with individual resorbable sutures (Vicryl 3-0, Johnson \& Johnson, Brussels, Belgium). The animals were sacrificed after 1,4 , and 12 weeks using $\mathrm{CO}_{2}$ suffocation. Implants were retrieved with 2 
to $4 \mathrm{~mm}$ soft tissue margin, and fixed in $4 \%$ buffered formalin at $8^{\circ} \mathrm{C}$ for 2 weeks.

\section{Histological sections and histomorphometrical evaluation}

Fixed specimens were dehydrated in a graded series of ethanol and embedded in methylmethacrylate. After polymerization, three $10 \mu \mathrm{m}$ thick sections were prepared per implant, using a modified sawing microtome technique. ${ }^{27}$ Sections were double stained with methylene blue and basic fuchsine.

Sections were histologically evaluated for bone morphology, fibrous tissue capsule formation, inflammatory reaction, and foreign body reaction, using light microscopy. The lamellar structure of remodeled bone was evaluated using polarizing microscopy. Computer-based histomorphometrical analysis (using Leica QWin Standard v3.0 software) was performed to determine the cross-sectional area of the scaffold material and of the newly formed bone in the implants. The distribution of bone within scaffolds was analyzed by dividing the implant area into the outermost $200 \mu \mathrm{m}$ boundary layer and the remaining interior part. An average of the measurements from three sections per implant was used for the statistical analysis.

\section{Statistics}

Statistical analyses were performed using the SPSS v11.0 software package (SPSS, Chicago, IL). Data were analyzed with one-way ANOVA followed by Tukey's post hoc test. Differences were considered significant at a $95 \%$ confidence level.

\section{RESULTS}

\section{Implant retrieval}

Four animals did not recover from the operation and were lost from the follow-up during the first two postoperative days. Healing was uneventful for the remaining 14 animals, and they were sacrificed at $1(n=4), 4(n=5)$, and $12(n=5)$ weeks of implantation. At retrieval no clinical signs of inflammation or adverse reactions were observed. All implants were surrounded by a thin reaction-free fibrous tissue capsule.

\section{Descriptive light microscopy}

One week implants. In coated implants the smallest pores were partially occluded by sol-gel aggregates. $\mathrm{TiO}_{2}$ aggregates had a granular appearance, while TiSi aggregates formed a more continuous phase. One cpTi and one $\mathrm{TiO}_{2}$ scaffold were partially filled by a resolving hematoma caused by excessive bleeding during implantation, and they were excluded from the subsequent histomorphometrical analysis.

After 1 week of implantation, a few mononuclear leucocytes were observed in and around the scaffolds. All scaf- folds were surrounded by loosely aligned connective tissue that formed a 4-10 cell layers thick capsule. The scaffolds were already filled with well-vascularized loose fibrous connective tissue. Multiple patches of unorganized mineralizing tissue with scarce amounts of woven bone were seen in all implants (Fig. 1). Most of the mineralization was on the periphery of the scaffolds, and it was more abundant on the dorsal than on the ventral side. More number of sites with osteoblast-like cells and osteoid tissue expressing active bone formation were observed within $\mathrm{TiO}_{2}$ and cpTi scaffolds than within TiSi scaffolds.

Four week implants. Fibrous tissue in and around the scaffolds was more organized and contained more collagen fibers compared to 1 week implants. The number of mononuclear inflammatory cells was comparable to that observed in 1 week implants. Occasional multinuclear cells were

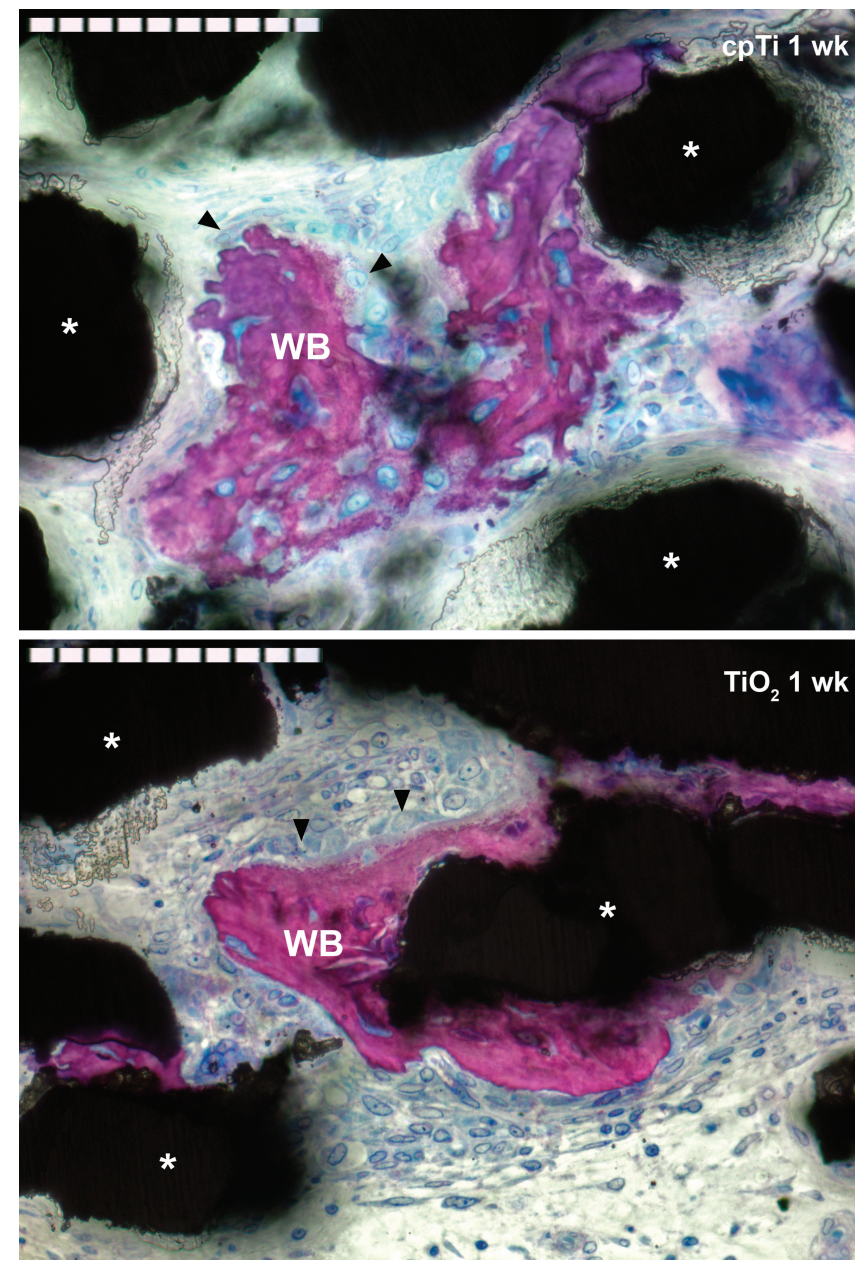

FIG. 1. Bone formation at 1 week of implantation. Bone formation within cpTi scaffolds (above) was typically observed between the titanium fibers (white asterisks), whereas within coated scaffolds (below) bone formed directly on the surface of the fibers. Rounded osteoblast-like cells (black arrowheads) are seen on the surface of woven bone (WB). Scale bar $100 \mu \mathrm{m}$. Color images available online at www.liebertpub.com/ten. 


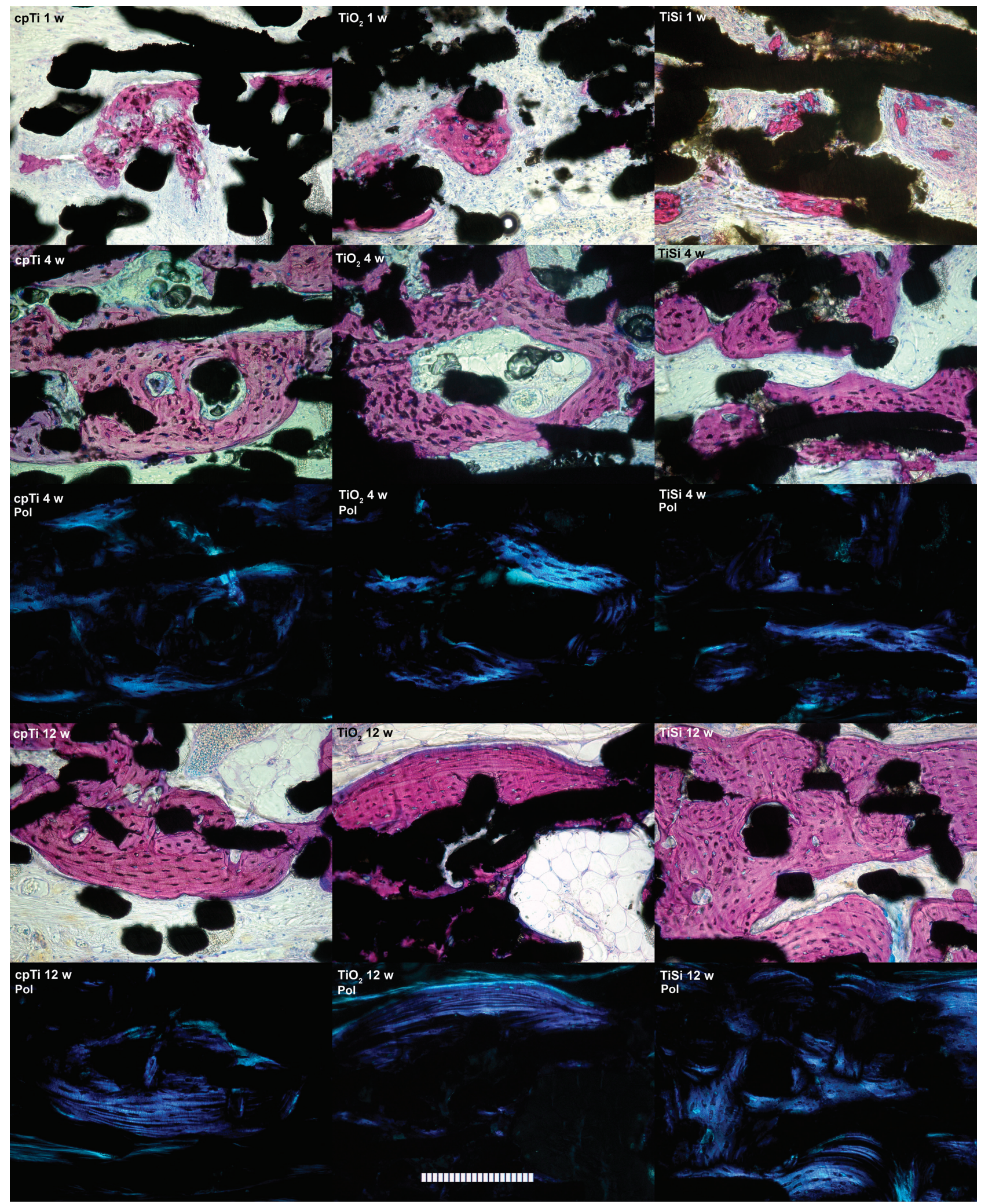

FIG. 2. Typical patterns of bone formation within subcutaneously implanted cpTi (left column), $\mathrm{TiO}_{2}$ (center column), and TiSi (right column) scaffolds. Sections at each time point are from the same animal. After 1 week, multiple patches of unorganized mineralizing tissue with scarce amounts of woven bone were seen in all implants. The amount of bone-like tissue clearly increased from 1 to 4 weeks. After 12 weeks the structure of bone, with bone marrow-like tissue, was further matured and mesh fibers were embedded in lamellar bone, which can be clearly seen with polarizing microscopy (Pol). Scale bar $200 \mu \mathrm{m}$. Color images available online at www.liebertpub.com/ten. 
observed with all scaffold types, slightly more with coated scaffolds than with uncoated scaffolds. However, the number of multinuclear cells observed in all implants was within the range of $0-5$ cells/section. The appearance of sol-gel aggregates within coated scaffolds was similar to that noticed in 1 week implants.

The amount of bone-like tissue clearly increased from 1 to 4 weeks with all scaffold types. Large areas of mineralized matrix with embedded osteocytes were observed. On the surface of the deposited bone, osteoid, active plump osteoblasts, and flattened lining cells as well as occasional resorption pits could be seen. With cpTi and $\mathrm{TiO}_{2}$ scaffolds, bone tissue formed large, continuous areas, while with TiSi scaffolds bone still existed in multiple discrete areas interspersed with fibrous tissue. Three out of five cpTi scaffolds also contained diverse amounts of adipose tissue at their periphery. In contrast, the bone within two $\mathrm{TiO}_{2}$ scaffolds exhibited large cavities filled with fibrous and adipose tissue, but no fatty tissue was seen outside the bone. Further, these scaffolds showed bone formation not only inside the implants but also on their outer surface. No fatty tissue was observed within any of the TiSi scaffolds. Bone apposition occurred in direct contact with sol-gel-coated meshes, while a thin layer of unmineralized fibrous tissue was often observed surrounding the cpTi mesh fibers (Fig. 2). Also, direct bone formation was seen on larger sol-gel aggregates while small, discrete sol-gel particles were surrounded by fibrous connective tissue.

Twelve week implants. The appearance of the fibrous capsule or the sol-gel aggregates, and the number of inflammatory and multinuclear cells had not changed from 4 to 12 weeks. Fibrous tissue inside the scaffolds was mostly replaced by adipose tissue that typically formed discrete areas within mineralized tissue, resembling bone marrow. The structure of bone was further matured and contained larger areas of remodeled lamellar bone. A layer of flattened cells covered the bone surface, and rounded osteoblasts were almost absent. Numerous resorption pits were observed in all specimens (Fig. 3). With all scaffold types, direct bonetitanium contact was observed when titanium mesh fibers were embedded within bone. With cpTi and $\mathrm{TiO}_{2}$ scaffolds, more bone marrow-like tissue within bone cavities were observed than before. The structure of bone tissue with $\mathrm{TiO}_{2}$ scaffolds even resembled that of cancellous bone. With TiSi scaffolds the amount of bone tissue had increased, and the previously discrete areas of bone were growing together. Some fibrous tissue could be seen at the periphery of the scaffolds, while the cavities in bone were almost exclusively filled with bone marrow-like tissue. Three $\mathrm{TiO}_{2}$ and all TiSi scaffolds showed some bone formation also on their outer surface.

\section{Histomorphometry}

For the histomorphometrical analysis only stained mineralized tissue within the scaffolds was defined as bone (Fig. 4).

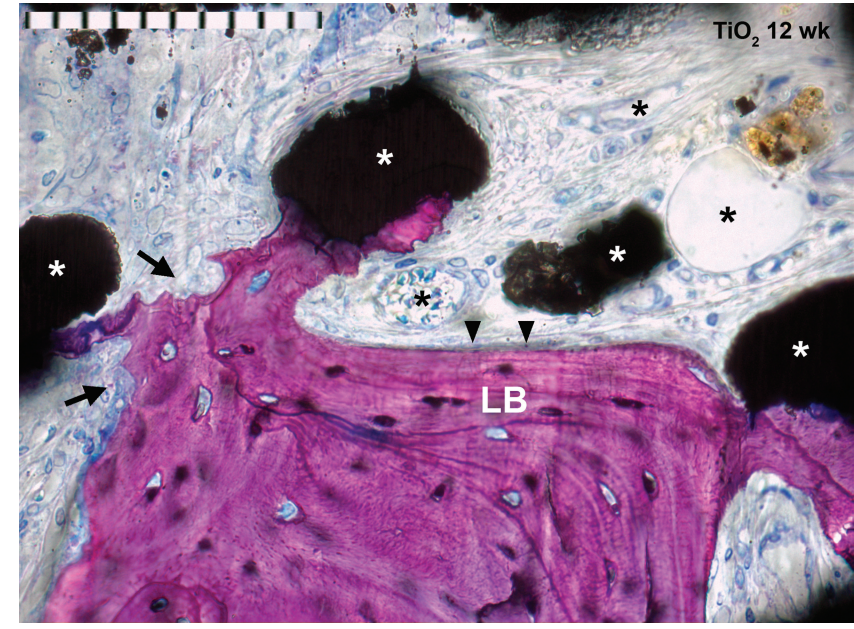

FIG. 3. Bone remodeling at 12 weeks within $\mathrm{TiO}_{2}$ scaffold. Bone and fibroconnective tissue with blood vessels (black asterisks) are seen between the titanium fibers (white asterisks). Lamellar bone (LB) with embedded osteocytes is covered by flattened lining cells (black arrowheads). Several resorption pits (black arrows) were also observed. Scale bar $100 \mu \mathrm{m}$. Color images available online at www.liebertpub.com/ten.

Results of bone formation within the whole implant area are summarized in Table 1. After 1 week of implantation, bone formation was very limited with all scaffold types. However, significantly more bone was observed with cpTi than with TiSi scaffolds $(p<0.05)$. At 4 weeks, the amount of bone had increased to approximately $15 \%, 13 \%$, and $10 \%$ for cpTi, $\mathrm{TiO}_{2}$, and TiSi scaffolds, respectively, with no statistical differences between scaffold types. Only TiSi scaffolds showed further increase in bone area by 12 weeks $(p<0.01)$. At that time the bone areas were $18 \%, 16 \%$, and $21 \%$, respectively, and the difference between $\mathrm{TiO}_{2}$ and TiSi scaffolds was statistically significant $(p<0.05)$.

The sol-gel aggregates resulted in the decrease of measured porosity within coated scaffolds by approximately $10 \%$ (data not shown). Bone formation within open porosity of the implants is summarized in Table 2. Again, a five to ten times increase in bone formation was noticed from 1 to 4 weeks for all scaffold types, and TiSi scaffolds were the only ones showing further increase in pore filling from 4 to 12 weeks $(p<0.01)$. No statistically significant differences between scaffold types were observed at any time of implantation.

The distribution of bone within scaffolds changed during the implantation period (Table 3). At 1 week, most of the mineralization was found within the outermost $200 \mu \mathrm{m}$ boundary layer of the scaffolds (corresponding altogether to 50\% of the implant thickness and $60 \%$ of the implant area). At 4 weeks the situation had reversed, and only $20-30 \%$ of bone existed in the periphery of the scaffolds. No great change in bone distribution occurred from 4 to 12 weeks, but the difference between cpTi and $\mathrm{TiO}_{2}$ scaffolds became statistically significant. This corresponded to histological findings, which showed more even distribution of bone-like tissue 

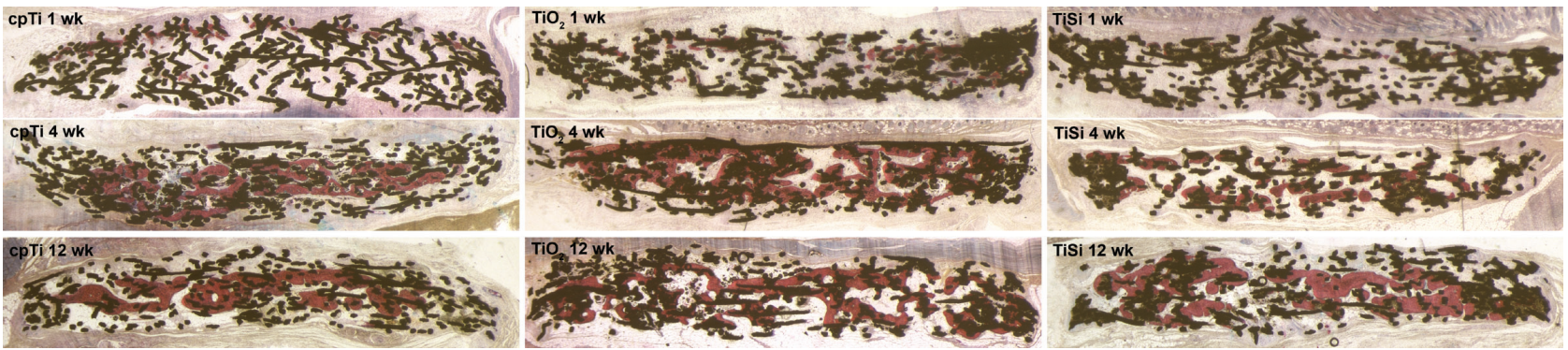

FIG. 4. Distribution and amount of bone within cpTi (left column), $\mathrm{TiO}_{2}$ (center column), and TiSi (right column) scaffolds. For histomorphometric analysis the percentage of mineralized tissue was measured within the whole titanium fiber mesh and within the open porosity. Mineralization can be seen in the periphery of the scaffolds at 1 week. Later, the amount of bone increased and it was more evenly distributed. Only coated scaffolds showed bone also on their outer surfaces. Scaffolds are $6 \mathrm{~mm}$ in diameter and $0.8 \mathrm{~mm}$ thick. Color images available online at www.liebertpub.com/ten.

within sol-gel-coated scaffolds compared to the uncoated scaffolds.

\section{DISCUSSION}

It has been shown that cell-loaded titanium fiber scaffolds have bone-forming potential in ectopic rat models. ${ }^{28,29}$ Bone formation further increases when calcium phosphate-coated scaffolds are used. ${ }^{14}$ However, such coatings are ultimately resorbed in vivo, exposing the underlying metal surface and potentially resulting in the loss of existing contact with surrounding tissues. ${ }^{30}$ On the other hand, nonresorbable solgel $\mathrm{TiO}_{2}$ coatings have been shown to increase both bone ${ }^{20}$ and soft-tissue ${ }^{31}$ attachment to titanium implants. Under culture conditions, osteoblast response on planar surfaces ${ }^{24}$ but not in porous scaffolds, ${ }^{25}$ was found to be further enhanced by incorporation of a reactive silica phase in the coating. We therefore hypothesized that nonresorbable bioactive coatings, with or without a silica phase, have good potential to enhance ectopic bone formation. We set out to study bone formation on sol-gel-coated titanium fiber mesh scaffolds loaded with osteoprogenitor cells in rat subcutaneous environment.

In our previous studies, sol-gel-derived coatings have been prepared using a dipping method. ${ }^{23-25}$ This method, however, is not optimal for porous substrates because the high viscosity of the coating sols may result in uneven coating thickness on scaffold surfaces. This was also noticed in the present study as we found a large amount of aggregated coating material inside the $\mathrm{TiO}_{2}$ and TiSi scaffolds. Although the aggregates did not seem to result in particleinduced inflammation, they did alter the pore size distribution and the porous structure of the meshes. This reduces the permeability of the scaffold and occludes some of the smallest pores. More controlled coatings are thus preferred. This could possibly be achieved by lowering the viscosity of the coating sols, by reducing the number of coating layers, or by removing the excess sol by centrifugal force before heat treatment. In other words, for future work, spin coating might be more suitable for porous scaffolds than the traditional dip-coating technique used in the current study setup. ${ }^{32,33}$

The scaffolds were seeded with cells using a previously optimized protocol. ${ }^{28,34}$ The harvested bone marrow stromal cells were precultured in the presence of dexamethasone to allow for their early differentiation toward the osteogenic lineage. The osteoblasts were loaded in suspension to achieve a uniform distribution of cells throughout the scaffolds. The cells were subsequently allowed to attach and spread only for 1 day prior to implantation, as this results in more active bone formation than longer culture periods. However, significantly longer cultures of cell-scaffold constructs will be needed if the precultures are performed without dexamethasone. ${ }^{35,36}$

Much higher ectopic bone formation with uncoated titanium scaffolds was observed in this study (15\% to $18 \%$ ) than in our previous research (less than 10\%) using similar

Table 1. Cross-Sectional Area of Bone within Whole Implants DURING 12 WEEKS OF IMPLANTATION

\begin{tabular}{lcccr}
\hline & $c p T i$ & $\mathrm{TiO}_{2}$ & $\mathrm{TiSi}$ & $p<0.05$ \\
\hline 1 week & $3.0 \pm 0.4 \%^{\mathrm{a}}$ & $1.5 \pm 1.4 \%^{\mathrm{a}}$ & $0.8 \pm 0.5 \%$ & $\mathrm{cpTi}>\mathrm{TiSi}$ \\
4 weeks & $15.0 \pm 3.9 \%$ & $12.7 \pm 4.6 \%$ & $9.9 \pm 2.6 \%$ & $\mathrm{NS}$ \\
12 weeks & $18.4 \pm 1.5 \%$ & $16.1 \pm 2.7 \%$ & $20.7 \pm 2.1 \%$ & $\mathrm{TiO}_{2}<\mathrm{TiSi}$ \\
$p<0.01$ & $1 \mathrm{wk}<4 \mathrm{wk}$ & $1 \mathrm{wk}<4 \mathrm{wk}$ & $1 \mathrm{wk}<4 \mathrm{wk}<12 \mathrm{wk}$ & \\
\hline
\end{tabular}

$n=5$ if not otherwise stated; ${ }^{\mathrm{a}} n=3,{ }^{\mathrm{b}} n=4$

NS $=$ Not significant 
Table 2. Cross-Sectional Area of Bone within Open Porosity DURING 12 WEEKS OF IMPLANTATION

\begin{tabular}{lcccc}
\hline & $c p T i$ & \multicolumn{1}{c}{$\mathrm{TiO}_{2}$} & $\mathrm{TiSi}$ & $p<0.05$ \\
\hline 1 week & $5.0 \pm 0.4 \%^{\mathrm{a}}$ & $3.0 \pm 2.6 \%^{\mathrm{a}}$ & $1.6 \pm 1.2 \%^{\mathrm{b}}$ & $\mathrm{NS}$ \\
4 weeks & $23.9 \pm 5.8 \%$ & $23.0 \pm 5.5 \%$ & $16.4 \pm 3.6 \%$ & $\mathrm{NS}$ \\
12 weeks & $25.9 \pm 1.6 \%$ & $27.3 \pm 7.0 \%$ & $34.1 \pm 5.3 \%$ & $\mathrm{NS}$ \\
$p<0.01$ & $1 \mathrm{wk}<4 \mathrm{wk}$ & $1 \mathrm{wk}<4 \mathrm{wk}$ & $1 \mathrm{wk}<4 \mathrm{wk}<12 \mathrm{wk}$ & \\
\hline
\end{tabular}

$n=5$ if not otherwise state; ${ }^{\mathrm{a}} n=3,{ }^{\mathrm{b}} n=4$

$\mathrm{NS}=$ Not significant

experimental protocol. ${ }^{29,37}$ The degree of osteogenic differentiation in primary bone marrow stromal cell cultures is subject to variation, and the initial phenotype of seeded cells is known to affect the amount of ectopic bone formation. ${ }^{38,39}$ This can possibly explain the discrepancy between our own experiments. No definitive answer can be given, however, and it emphasizes the difficulties in comparing results from different studies, and the importance of using relevant control samples in all experiments.

The amount of bone within the whole implant area, as well as within the open porosity, did not show substantial differences, but the kinetics of bone formation differed between scaffold types. With cpTi and $\mathrm{TiO}_{2}$ scaffolds the maximal amount of bone was reached already after 4 weeks of implantation, whereas bone formation with TiSi scaffolds continued throughout the experiment. $\mathrm{TiO}_{2}$ scaffolds seemed to show the most active bone formation and remodeling. Interestingly, at the level of light microscopic evaluation, ectopic bone formation occurred directly on the $\mathrm{TiO}_{2^{-}}$and TiSi-coated titanium, as well as on larger sol-gel aggregates at all times. Such behavior resembles ectopic bone formation within porous calcium phosphate ceramics, and indicates good attachment of seeded cells to the underlying substrate. ${ }^{40,41}$ In contrast, bone formation within cpTi meshes usually started away from the titanium surface, and individual fibers were mostly surrounded by a thin layer of fibrous unmineralized tissue still at 4 weeks. As bone formation proceeded, and mesh fibers were embedded in bone matrix, all materials showed good bone contact.

Bone seemed to grow out from multiple starting points, as indicated by individual mineralizing tissue patches at 1 week. Further, discrete bony areas were observed within TiSi scaffolds even after 4 weeks of implantation. In addi- tion to direct material effects, decreased cell-seeding efficiency might also have contributed to the delayed bone formation within TiSi scaffolds. ${ }^{42}$ However, this aspect was not analyzed in the current study. When the amount of bone increased, a more continuous tissue was formed, irrespective of the scaffold type. Mineralization began from the periphery of scaffolds, where the amount of seeded cells was likely to be the highest and diffusion limitations the lowest. However, almost every specimen showed ingrowth of wellvascularized connective tissue through the mesh already at 1 week. This is very important for the survival of seeded cells and for the subsequent bone formation. ${ }^{43,44}$ Later bone formation was most evident in the middle of the scaffolds, and bone grew in direct contact with mesh fibers, with no intervening fibrous tissue. Coated scaffolds showed enhanced osteoconductivity and more dispersed bone formation than the uncoated ones. Similar results were recently obtained when uncoated titanium mesh was compared with a calcium phosphate ceramic. ${ }^{37}$ Bone formation on the outer surface of only the sol-gel-coated scaffolds further advocates their increased osteoconductivity. Again, this finding resembles ectopic bone formation within ceramic scaffolds. ${ }^{45,46}$ Subsequently, the coatings should also be tested in an orthotopic site to analyze their behavior more precisely.

\section{CONCLUSIONS}

The amount of ectopic bone formed with bone marrow stromal cell-seeded $\mathrm{TiO}_{2^{-}}$and TiSi-coated scaffolds was comparable to that with uncoated titanium scaffolds. However, differences were observed in the kinetics of bone formation, and at the implant-bone interface. A notable

Table 3. Fraction of Bone in the Outermost $200 \mu$ m Boundary Layer of the Scaffolds

\begin{tabular}{|c|c|c|c|c|}
\hline & $c p T i$ & $\mathrm{TiO}_{2}$ & $\mathrm{TiSi}$ & $p<0.05$ \\
\hline 1 week & $72.2 \pm 9.5 \%^{\mathrm{a}}$ & $68.8 \pm 18.0 \%^{\mathrm{a}}$ & $84.5 \pm 15.3 \%^{b}$ & NS \\
\hline 4 weeks & $22.9 \pm 11.3 \%$ & $32.1 \pm 7.9 \%$ & $29.8 \pm 12.8 \%$ & NS \\
\hline 12 weeks & $24.5 \pm 7.1 \%$ & $43.1 \pm 8.8 \%$ & $35.7 \pm 6.7 \%$ & cpTi $<\mathrm{TiO}_{2}$ \\
\hline$p<0.01$ & $1 \mathrm{wk}>4 \mathrm{wk}$ & $1 \mathrm{wk}>4 \mathrm{wk}$ & $1 \mathrm{wk}>4 \mathrm{wk}$ & \\
\hline
\end{tabular}


difference was that the sol-gel coatings resulted in bone formation throughout the implants, whereas uncoated implants showed bone formation mainly in the center of the scaffolds.

\section{ACKNOWLEDGMENTS}

This work was carried out within the Bio- and Nanopolymers Research Group of the Academy of Finland (CoE program 77317, Academy of Finland Grant no: 200077) and was partially funded by the Finnish National Technology Agency, TEKES (no: 40319/02). The ZonMw grant 910-31802 is also acknowledged.

\section{REFERENCES}

1. Yaszemski, M.J., Payne, R.G., Hayes, W.C., Langer, R., and Mikos, A.G. Evolution of bone transplantation: molecular, cellular and tissue strategies to engineer human bone. Biomaterials 17, 175, 1996.

2. Lane, J.M., Tomin, E., and Bostrom, M.P.G. Biosynthetic bone grafting. Clin. Orthop. 367S, S107, 1999.

3. Finkemeier, C.G. Bone-grafting and bone-graft substitutes. J. Bone Joint Surg. Am. 84A, 454, 2002.

4. Krebsbach, P.H., Kuznetsov, S.A., Bianco, P., and Robey, P.G. Bone marrow stromal cells: characterization and clinical application. Crit. Rev. Oral Biol. Med. 10, 165, 1999.

5. Derubeis, A.R., and Cancedda, R. Bone marrow stromal cells (BMSCs) in bone engineering: limitations and recent advances. Ann. Biomed. Eng. 32, 160, 2004.

6. Ishaug-Riley, S.L., Crane, G.M., Gurlek, A., Miller, M.J., Yasko, A.W., Yaszemski, M.J., and Mikos, A.G. Ectopic bone formation by marrow stromal osteoblast transplantation using poly(dl-lactic-co-glycolic acid) foams implanted into the rat mesentery. J. Biomed. Mater. Res. 36, 1, 1997.

7. Kuboki, Y., Takita, H., Kobayashi, D., Tsuruga, E., Inoue, M., Murata, M., Nagai, N., Dohi, Y., and Ohgushi, H. Bmpinduced osteogenesis on the surface of hydroxyapatite with geometrically feasible and nonfeasible structures: topology of osteogenesis. J. Biomed. Mater. Res. 39, 190, 1998.

8. Nishikawa, M., Myoui, A., Ohgushi, H., Ikeuchi, M., Tamai, N., and Yoshikawa, H. Bone tissue engineering using novel interconnected porous hydroxyapatite ceramics combined with marrow mesenchymal cells: quantitative and three-dimensional image analysis. Cell Transplant. 13, 367, 2004.

9. Ohgushi, H., Okumura, M., Tamai, S., Shors, E.C., and Caplan, A.I. Marrow cell induced osteogenesis in porous hydroxyapatite and tricalcium phosphate-a comparative histomorphometric study of ectopic bone-formation. J. Biomed. Mater. Res. 24, 1563, 1990.

10. Radder, A.M., van Blitterswijk, C.A., Leenders, H., Inoue, K., Okumura, M., and Ohgushi, H. Gene-expression and proteinactivity in bone-bonding and nonbonding peo/pbt copolymers. J. Mater. Sci. Mater. Med. 5, 582, 1994.

11. Arinzeh, T.L., Tran, T., McAlary, J., and Daculsi, G. A comparative study of biphasic calcium phosphate ceramics for human mesenchymal stem-cell-induced bone formation. Biomaterials 26, 3631, 2005.

12. Mauney, J.R., Jaquiery, C., Volloch, V., Herberer, M., Martin, I., and Kaplan, D.L. In vitro and in vivo evaluation of differentially demineralized cancellous bone scaffolds combined with human bone marrow stromal cells for tissue engineering. Biomaterials 26, 3173, 2005.

13. Takaoka, T., Okumura, M., Ohgushi, H., Inoue, K., Takakura, Y., and Tamai, S. Histological and biochemical evaluation of osteogenic response in porous hydroxyapatite coated alumina ceramics. Biomaterials 17, 1499, 1996.

14. Vehof, J.W.M., van den Dolder, J., de Ruijter, J.E., Spauwen, P.H.M., and Jansen, J.A. Bone formation in cap-coated and noncoated titanium fiber mesh. J. Biomed. Mater. Res. Part A 64A, 417, 2003.

15. van den Dolder, J., Farber, E., Spauwen, P.H.M., and Jansen, J.A. Bone tissue reconstruction using titanium fiber mesh combined with rat bone marrow stromal cells. Biomaterials 24, 1745, 2003.

16. Kokubo, T., Kim, H.-M., Kawashita, M., and Nakamura, T. Bioactive metals: preparation and properties. J. Mater. Sci. Mater. Med. 15, 99, 2004.

17. Liang, B., Fujibayashi, S., Neo, M., Tamura, J., Kim, H.-M., Uchida, M., Kokubo, T., and Nakamura, T. Histological and mechanical investigation of the bone-bonding ability of anodically oxidized titanium in rabbits. Biomaterials 24, 4959, 2003.

18. Son, W.W., Zhu, X.L., Shin, H.I., Ong, J.L., and Kim, K.H. In vivo histological response to anodized and anodized/hydrothermally treated titanium implants. J. Biomed. Mater. Res. Part B 66B, 520, 2003.

19. Sul, Y.T., Johansson, C., Byon, E., and Albrektsson, T. The bone response of oxidized bioactive and non-bioactive titanium implants. Biomaterials 26, 6720, 2005.

20. Li, P., and de Groot, K. Calcium phosphate formation within sol-gel prepared titania in vitro and in vivo. J. Biomed. Mater. Res. 27, 1495, 1993.

21. Peltola, T., Jokinen, M., Rahiala, H., Pätsi, M., Heikkilä, J., Kangasniemi, I., and Yli-Urpo, A. Effect of aging time of sol on structure and in vitro calcium phosphate formation of sol-gel-derived titania films. J. Biomed. Mater. Res. 51, 200, 2000.

22. Hench, L.L. Bioactive materials: the potential for tissue regeneration. J. Biomed. Mater. Res. 41, 511, 1998.

23. Jokinen, M., Patsi, M., Rahiala, H., Peltola, T., Ritala, M., and Rosenholm, J.B. Influence of sol and surface properties on in vitro bioactivity of sol-gel-derived $\mathrm{TiO}_{2}$ and $\mathrm{TiO}_{2}-\mathrm{SiO}_{2}$ films deposited by dip-coating method. J. Biomed. Mater. Res. 42, 295, 1998.

24. Areva, S., Ääritalo, V., Tuusa, S., Jokinen, M., Lindén, M., and Peltola, T. Sol-gel derived $\mathrm{TiO}_{2}-\mathrm{SiO}_{2}$ implant coatings for direct tissue attachment. Part II: Evaluation of cell response. J. Mater. Sci.-Mater. Med., accepted for publication.

25. Meretoja, V.V., de Ruijter, J.E., Peltola, T.O., Jansen, J.A., and Närhi, T.O. Osteoblast differentiation with titania and titania-silica-coated titanium fiber meshes. Tissue Eng. 11, 1489, 2005.

26. Maniatopoulos, C., Sodek, J., and Melcher, A.H. Bone formation in vitro by stromal cells obtained from bone marrow of young adult rats. Cell Tissue Res. 254, 317, 1988. 
27. van der Lubbe, H.B., Klein, C.P., and de Groot, K. A simple method for preparing thin (10 microm) histological sections of undecalcified plastic embedded bone with implants. Stain Technol. 63, 171, 1988.

28. van den Dolder, J., Vehof, J.W., Spauwen, P.H., and Jansen, J.A. Bone formation by rat bone marrow cells cultured on titanium fiber mesh: effect of in vitro culture time. J. Biomed. Mater. Res. 62, 350, 2002.

29. Hartman, E.H.M., Vehof, J.W.M., de Ruijter, J.E., Spauwen, P.H.M., and Jansen, J.A. Ectopic bone formation in rats: the importance of vascularity of the acceptor site. Biomaterials $\mathbf{2 5}$, 5831, 2004.

30. Williams, D.F., and Williams, R.L. Degradative effects of the biological environment on metals and ceramics. In: Ratner, B.D., Hoffman, A.S., Schoen, F.J., and Lemons, J.E., eds. Biomaterials Science : An Introduction to Materials in Medicine. San Diego: Academic Press, 1996, pp. 260-266.

31. Areva, S., Paldan, H., Peltola, T., Närhi, T., Jokinen, M., and Lindén, M. Use of sol-gel-derived titania coating for direct soft tissue attachment. J. Biomed. Mater. Res. 70A, 169, 2004.

32. Gomez-Vega, J.M., Iyoshi, M., Kim, K.Y., Hozumi, A., Sugimura, H., and Takai, O. Spin casted mesoporous silica coatings for medical applications. Thin Solid Films 398, 615, 2001.

33. Kim, H.W., Kim, H.E., Salih, V., and Knowles, J.C. Hydroxyapatite and titania sol-gel composite coatings on titanium for hard tissue implants; mechanical and in vitro biological performance. J. Biomed. Mater. Res. Part B 72, 1, 2005.

34. Sikavitsas, V.I., van den Dolder, J., Bancroft, G.N., Jansen, J.A., and Mikos, A.G. Influence of the in vitro culture period on the in vivo performance of cell/titanium bone tissueengineered constructs using a rat cranial critical size defect model. J. Biomed. Mater. Res. 67A, 944, 2003.

35. Yoshikawa, T., Ohgushi, H., and Tamai, S. Immediate bone forming capability of prefabricated osteogenic hydroxyapatite. J. Biomed. Mater. Res. 32, 481, 1996.

36. Kruyt, M.C., Dhert, W.J.A., Oner, C., van Blitterswijk, C.A., Verbout, A.J., and de Bruijn, J.D. Optimization of bone-tissue engineering in goats. J. Biomed. Mater. Res. Part B 69B, 113, 2004.

37. Hartman, E.H.M., Vehof, J.W.M., Spauwen, P.H.M., and Jansen, J.A. Ectopic bone formation in rats: the importance of the carrier. Biomaterials 26, 1829, 2005.

38. Yoshikawa, T., Ohgushi, H., Akahane, M., Tamai, S., and Ichijima, K. Analysis of gene expression in osteogenic cultured marrow/hydroxyapatite construct implanted at ectopic sites: a comparison with the osteogenic ability of cancellous bone. J. Biomed. Mater. Res. 41, 568, 1998.
39. Holtorf, H.L., Jansen, J.A., and Mikos, A.G. Ectopic bone formation in rat marrow stromal cell/titanium fiber mesh scaffold constructs: effect of initial cell phenotype. Biomaterials 26, 6208, 2005.

40. Goshima, J., Goldberg, V.M., and Caplan, A.I. Osteogenic potential of culture-expanded rat marrow-cells as assayed in vivo with porous calcium-phosphate ceramic. Biomaterials 12, 253, 1991.

41. Yoshikawa, T., Ohgushi, H., Okumura, M., Tamai, S., Dohi, Y., and Moriyama, T. Biochemical and histological sequences of membranous ossification in ectopic site. Calcif. Tissue Int. 50, 184, 1992.

42. Wang, J.Y., Asou, Y., Sekiya, I., Sotome, S., Orii, H., and Shinomiya, K. Enhancement of tissue engineered bone formation by a low pressure system improving cell seeding and medium perfusion into a porous scaffold. Biomaterials 27, 2738, 2006.

43. Kruyt, M.C., de Bruijn, J.D., Wilson, C.E., Oner, F.C., van Blitterswijk, C.A., Verbout, A.J., and Dhert, W.J.A. Viable osteogenic cells are obligatory for tissue-engineered ectopic bone formation in goats. Tissue Eng. 9, 327, 2003.

44. Pelissier, P., Villars, F., Mathoulin-Pelissier, S., Bareille, R., Lafage-Proust, M.H., and Vilamitjana-Amedee, J. Influences of vascularization and osteogenic cells on heterotopic bone formation within a madreporic ceramic in rats. Plast. Reconstr. Surg. 111, 1932, 2003.

45. Dong, J.A., Uemura, T., Shirasaki, Y., and Tateishi, T. Promotion of bone formation using highly pure porous beta-tcp combined with bone marrow-derived osteoprogenitor cells. Biomaterials 23, 4493, 2002.

46. van Gaalen, S.M., Dhert, W.J.A., van den Muysenberg, A., Oner, F.C., van Blitterswijk, C., Verbout, A.J., and de Bruijn, J.D. Bone tissue engineering for spine fusion: an experimental study on ectopic and orthotopic implants in rats. Tissue Eng. 10, 231, 2004.

Address reprint requests to: Ville V. Meretoja, M.Sc. Department of Prosthetic Dentistry and Biomaterials Science Institute of Dentistry, University of Turku Lemminkäisenkatu 2 FI-20520 Turku Finland

E-mail: ville.meretoja@utu.fi 
